\title{
From the Editor
}

\author{
LOREN KAJIKAWA
}

Over the past year, while preparing to step into my role as editor of JSAM, I have witnessed how the journal draws its strength not only from the leadership and staff members at the Society for American Music and Cambridge University Press, but also from both the general membership of SAM and the broader interdisciplinary world of American music studies. I am grateful to former editor Karen Ahlquist, whose mentorship has been invaluable and whose shoes will be a challenge to fill; editorial associate Mark Davidson, whose wisdom and guidance has been essential; and Jason Michalek, who helped to assure a smooth transition by working closely with Holly Roberts, JSAM's new assistant editor. Thank you.

At its best, JSAM reflects the intellectual energies and scholarly commitments of its readers, serving as a reflection of the field and a force in its ongoing transformation. In this respect, the journal will continue to ask questions and explore issues that have become central to American music studies. And it will do so, I hope, by promoting an inclusive and critical sense of the field, interrogating power relations, and crossing disciplinary boundaries. The articles and reviews published in the current issue are examples of such an approach, and subsequent issues will continue to expand upon the great range of topics and methods that make our field such a vibrant and vital site of discourse and action. 